\title{
Pemanfaatan Tepung Tulang Ikan Cakalang (Katsuwonus pelamis) sebagai Sumber Kalsium dan Fosfor untuk Meningkatkan Nilai Gizi Biskuit
}

\author{
Ruslan A. Daeng ${ }^{1}$ \\ ${ }^{1}$ Staf Pengajar Prodi Teknologi Hasil Perikanan Fakultas Pertanian, Universitas Muhammadiyah Maluku Utara. Ternate. \\ Indonesia, \\ Email :ruslan daeng@yahoo.com

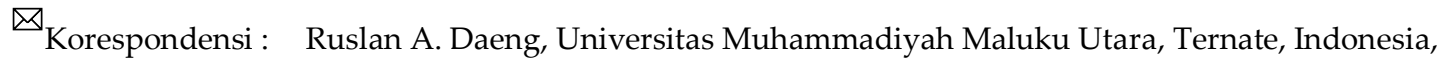 \\ Email :ruslandaeng@yahoo.com
}

\begin{abstract}
ABSTRAK.
Pengelolaan limbah dari industri perikanan di Maluku Utara belum optimal dilakukan sehingga menimbulkan dampak yang kurang baik terhadap lingkungan, padahal limbah tersebut dapat diolah lebih lanjut menjadi berbagai produk yang memiliki nilai ekonomis. Limbah pengolahan ikan seperti kepala, tulang, sisik dan kulit biasanya dibuang dan tidak dimanfaatkan oleh masyarakat atau industri perikanan. Limbah yang dihasilkan berupa padatan dan cairan cukup besar pada umumnya berkisar antara 40-50\% dari berat total ikan, tergantung jenis ikan yang diolah. Biskuit adalah jenis yang terbuat dari adonan keras melalui proses fermentasi atau pemeraman, berbentuk pipih yang mengarah kepada rasa asin dan relatif renyah, serta bila dipatahkan penampang potongannya berlapis-lapis. Tujuan penelitian ini adalah memanfaatkan limbah ikan cakalang berupa tulang yang akan dijadikan sebagai tepung untuk ditambahkan ke dalam bahan pembuatan biskuit dan untuk mengetahui mutu sensori dari produk biskuit meliputu kenampakan, bau, rasa dan tekstur. Sedangkan manfaat penelitian adalah untuk menambah informasi tentang pemanfaatan limbah hasil perikanan yaitu limbah tulang ikan cakalang yang ditambahkan ke dalam bahan pembuatan biscuit. Penelitian ini dilaksanakan pada bulan Juni sampai Agustus 2018 di Laboratorium Teknologi Hasil Perikanan (THP) Kampus A, Universitas Muhammadiyah Maluku Utara (UMMU) Kelurahan Sasa Kota Ternate Selatan dan di Institut Pertanian Bogor (IPB) untuk uji kimia. Dari hasil penilitian dapat disimpulakan bahwa darai hasil uju kimia menunjukan bahwa hasil kadar air $(2,01 \%$, 2,38\%), kadar abu (1,01\%, 2,83\%), dan kadar lemak $(22,00 \%, 22,94 \%)$ memberikan pengaruh nyata terhadap biscuit tepung tulang ikan cakalang, sedangkan protein, karbohidrat by difference, kalsium dan fosfor memberikan pengaruh tudak nyata terhadap biscuit tepung tulang ikan cakalang.
\end{abstract}

\section{Keywords: Biskuit, kalsium fosfor, tepung tulang ikan cakalang}

\section{PENDAHULUAN}

\subsection{Latar Belakang}

Indonesia adalah Negara kepulauan yang memiliki \pm 17.508 pulau dengan luas laut territorial 0.366 juta $\mathrm{km}^{2}$. Perairan nusantara 2.8 juta $\mathrm{km}^{2}$ dengan Zona Ekonomi Eksklusif (ZEE) 2.7 juta $\mathrm{km}^{2}$ sehingga total luas keseluruhan perairan 5.8 juta $\mathrm{km}^{2}$. Perairan laut yang luas ini mengandung berbagai jenis ikan yang merupakan sumber pangan dan komoditi perdagangan.Jenis ikan pelagis merupakan jenis ikan yang sangat potensial untuk di kembangkan.Khusus untuk ikan pelagis besar lebih didomonasi oleh ikan tuna (Thunnus sp) dan ikan cakalang (Katsuwonus pelamis).Potensi tuna dan cakalang di perairan Indonesia adalah \pm 780.040 ton (Dahuri, 2004).

Ikan cakalang selain sebagai komoditas dalam bentuk ekspor beku juga dimanfaatkan secara tradisional oleh masyarakat. Pengolahan tradisional yang sudah umum dikenal adalah ikan asap, ikan asin dan produk fermentasi seperti kecap ikan, terasi, bakasang dan tepung tulang ikan (Dahuri, 2004). Pada umumnya proses pengolahan ikan cakalang seperti pengasapan dan penggaraman hanya memanfaatkan bagian dagingnya saja, sedangkan bagian lainnya seperti isi perut dan tulang umumnya dibuang dan sebagiannya dimanfaatkan sebagai produk sampingan. 
Tulang Ikan merupakan salah satu limbah hasil perikanan yang dihasilkan dari industri pengolahan ikan, salah satunya limbah ikan cakalang.Limbah ini belum dimanfaatkan karena belum ada pabrik atau pihak manapun yang mengolahnya.Tulang merupakan salah satu bagian tubuh mahluk hidup yang paling banyak mengandung kalsium dan fosfor.Kalsium merupakan unsur penting yang sangat dibutuhkan oleh tubuh, karena mineral ini berfungsi dalam metabolisme dan pembentukan tulang (Anonim, 2008).Kekurangan kalsium dapat menyebabkan osteoporosis atau tulang menjadi retak dan osteomalasia atau tulang menjadi lunak.Sedangkan fosfor penting untuk fungsi otot dan selsel darah merah, pemeliharaan keseimbangan asam-basa, dan juga untuk sistem saraf.

Pemanfaatan tepung tulang ikan cakalang yang telah dikurangi kandungan lemak dan protein ditambahkan ke dalam produk biskuit agar mudah diserap oleh tubuh dan tidak menghasilkan bau tengik. Salah satu cara untuk meningkatkan nilai gizi biskuit adalah dengan penambahan tepung tulang ikan cakalang yang kaya akan kalsium dan fosfor (Thalib, 2009).

Biskuit adalah jenis yang terbuat dari adonan keras melalui proses fermentasi atau pemeraman, berbentuk pipih yang mengarah kepada rasa asin dan relatif renyah, serta bila dipatahkan penampang potongannya berlapis-lapis (Manley, 2001).Biskuitmerupakan makanan ringan yang sudah memasyarakat dan banyak dijumpai dipasaran.Hal ini setidaknya dapat dibuktikan dengan tersedianya biskuitdi hampir semua toko yang menjual makanan kecil diperkotaan maupun hingga warung-warung dipelosok desa.Gambaran tersebut diatas menandakan bahwa hampir semua lapisan masyarakat sudah terbiasa menikmatibiskuit.Biskuitdisukai karena teksturnya yang renyah dan berlapis-lapis serta rasanya yang gurih (Artama, 2001).

\subsection{Tujuan dan Manfaat Penilitian}

Tujuan penelitian ini adalah untuk mengetahui mutu secara kimiawi meliputi kadar air, kadar abu, kadar protein, kadar lemak, karbohidrat dan kalsium serta fosfor. Sedangkan manfaat penelitian adalah untuk menambah informasi tentang pemanfaatan limbah hasil perikanan yaitu limbah tulang ikan cakalang yang ditambahkan ke dalam bahan pembuatan biskuit sebagai sumber kalsium dan fosfor.

\section{METODOLOGI PENILITIAN}

\subsection{Waktu dan Tempat}

Penelitian ini dilaksanakan pada bulan Juni sampai Agustus 2018 di Laboratorium Teknologi Hasil Perikanan (THP) Kampus A, Universitas Muhammadiyah Maluku Utara (UMMU) Kelurahan Sasa Kota Ternate Selatan dan di Institut Pertanian Bogor (IPB) untuk uji kimia.

\subsection{Alat dan Bahan}

Alat-alat yang digunakan untuk membuat tepung tulang ikan cakalang adalah baskom, mesin penghancur, ayakan dan timbangan.Alat-alat yang digunakan dalam pembuatan biskuit adalah baskom, mixer, alat cetakan biskuit, Loyang, oven, piring, sendok, plastik bening dan alat tulis. Alat-alat yang digunakan untuk uji kimia adalah cawan porselin, desikator, labu Kjeldahl, alat ekstraksi Soxhlet, kertas saring Whatman No.42, erlemeyer, spektrofotometer, kuvet, pipet, kapas wool bebas lemak, tabung reaksi, gelas ukur dan alat-alat untuk uji organoleptik menggunakan lembaran scoresheet.

Bahan utama yang digunakan dalam pembuatan tepung tulang ikan adalah tulang ikan cakalang (Katsuwonus pelamis) diperoleh dari limbah hasil perikanan dan jeruk nipis. Bahan yang digunakan dalam pembuatan biskuit adalah tepung terigu (Cap segitiga Biru), tepung tulang ikan cakalang, margarin (Blue Band), mentega, baking powder, susu skim, susu cair, gula halus, ragi dan air. Bahan-bahan kimia yang digunakan untuk uji kimia biscuit aguades, $\mathrm{NaOH}, \mathrm{HCl}, \mathrm{H}_{3} \mathrm{BO}_{3}, \mathrm{H}_{2} \mathrm{SO}_{4}, \mathrm{H}_{2} \mathrm{O}$, tablet Kjeltab, larutan hexana, buffer asam dan basa.

\subsection{Tahapan Penilitian}

Pelaksanaan penilitian ini dilakukan dalam 2 (dua) tahapan, yaitu tahap pembuatan tepung tulang ikan cakalang dan tahap pembuatan biskuit dengan formulasi yang berbeda, yaitu penambahan tepung tulang ikan pada berbagai konsentrasi dan analisis mutu biskuit yang meliputi uji kimia.

\subsubsection{Pembuatan tepung tulang ikan cakalang}

Tulang ikan yang sudah dibersihkan direbus dalam suhu $100{ }^{\circ} \mathrm{C}$ selama \pm 1 jam dengan tiga kali perebusan, tulang ikan ditiriskan dalam wadah selanjutnya dikeringkan dengan menggunakan 
oven dengan suhu $100{ }^{\circ} \mathrm{C}$ selama \pm 1 jam sampai kering. Kemudian proses penghancuran tulang ikan dengan cara digiling dengan mesin penggiling setengah halus kemudian dihaluskan lagi dengan mengunakan mixer dan ditapis hingga menjadi tepung. Diagram alir pembuatan tepung tulang ikan cakalang dapat dilihat pada Gambar 1.

\subsubsection{Pembuatan Biskuit}

Proses pembuatan biskuit pada tahap awal, bahan-bahan seperti: margarine, mentega, baking powder, susu dan gula halus dicampur dan diaduk selama kurang lebih 10 menit. Setelah itu tepung terigu, ragi dan tepung tulang ikan dimasukan kedalam adonan dan diaduk secara merata. Air dengan gula halus dicampur hingga larut kemudian dicampur kedalam adonan sambil diaduk dengan tangan hingga licin,

Selanjutnya dilakukan pemeraman adonan selama 30 menit, bertujuan untuk menghasilkan adonan yang elastis mengembang.Kemudian adonan dipipihkan membentuk lembaran dan bahan pengisi di isi pada sebagian lembaran.

Adonan dicetak dengan menggunakan cetakan yang seragam. Biskuit dihasilkan dengan 3 tahapan pemanggangan bertingkat, yaitu (1) suhu $200^{\circ} \mathrm{C}$ selama 3 menit untuk mengeringkan biskuit, (2) $150{ }^{\circ} \mathrm{C}$ selama 5 menit untuk mematangkan biskuit dan (3) $100{ }^{\circ} \mathrm{C}$ selama 7 menit untuk mewarnai biskuit. Diagram alir proses pembuatan biskuit dapat dilihat Pada Gambar 2.

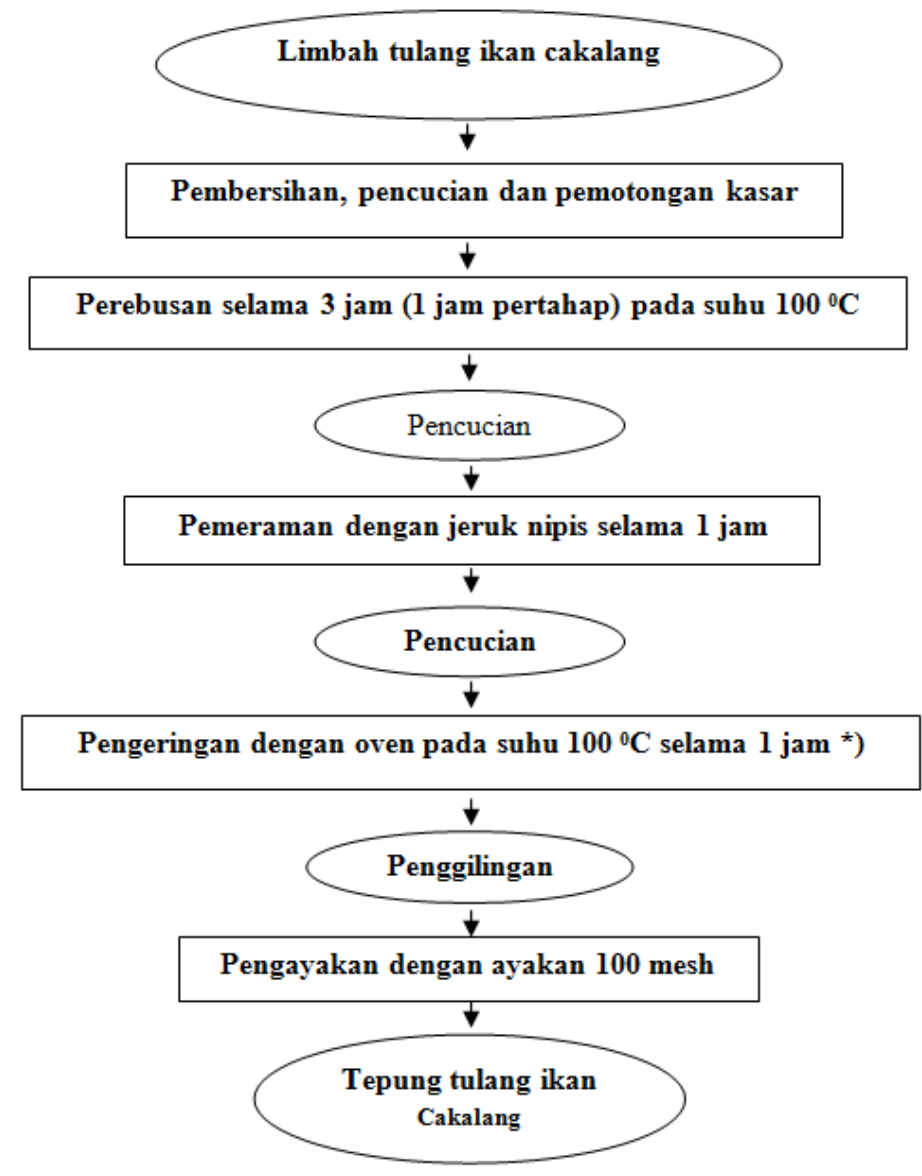

Ket : * Bagian yang dimodifikasi

Gambar 1. Diagram alir tepung tulang ikan cakalang (Modifikasi Vita, 2007)

\subsection{Prosedur Pengujian}

Pada penelitian ini dilakukan Uji kimia yang meliputi kadar air, kadar abu, kadar protein, kadar lemak, karbohidrat by difference, kadar kalsium, dan kadar fosfor.
a. Kadar air (AOAC, 1995)
b. Kadar abu (AOAC, 1995)
c. Kadar protein (AOAC, 1995) 
d. Kadar lemak (AOAC, 1995)

e. Karbohidrat by difference (AOAC, 1995)

f. Kadar kalsium

g. Kadar fosfor

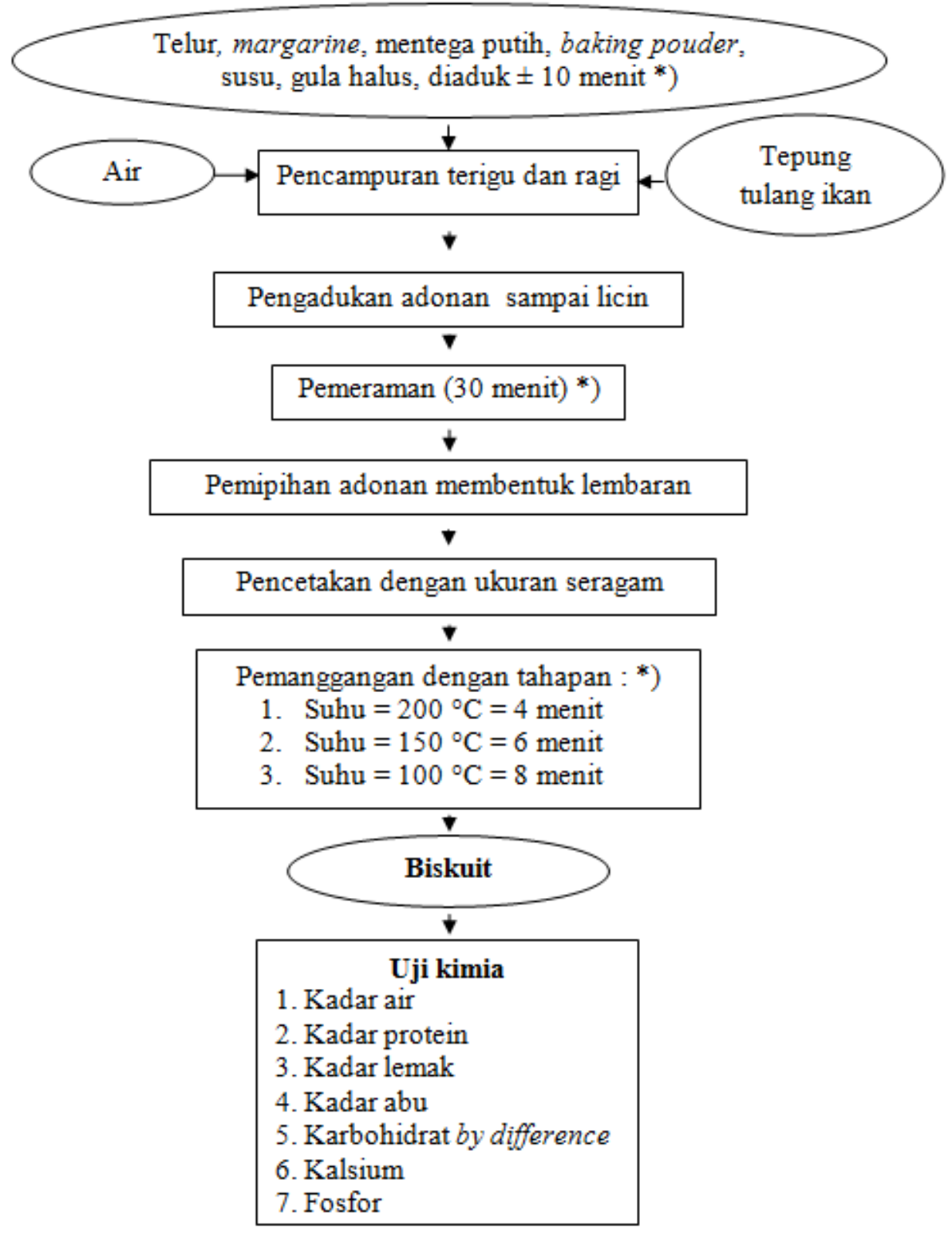

Ket $: *$ = Bagian yang dimodifikasi

Gambar 2. Diagram alir pembuatan biskuit

(Modifikasi Artama, 2001)

\subsection{Rancangan Percobaan dan Analisis Data}

Rancangan percobaan yang digunakan dalam penilitian ini adalah Rancangan Acak Lengkap (RAL) faktor tunggal, yaitu penambahan konsentrasi tepung tulang ikan cakalang dengan 3 taraf yaitu $\mathrm{A}_{1}=$ Kontrol, $\mathrm{A}_{2}=4,5 \mathrm{~g}$, dan $\mathrm{A}_{3}=10 \mathrm{~g}$. Masing - masing perlakuan diulang sebanyak 2 kali. Model Rancangan $: Y_{i j}=\mu+A_{i}+\varepsilon_{i j}$ (Steel dan Torrie, 1991).

Data hasil pengujian secara kimia dianalisis menggunakan analisis varian (Anova).Sedangkan data hasil uji organoleptik dihitung menggunakan nilai rata-rata dan standar Deviasi. Rumus matematik nilai rata-rata adalah :

$$
\bar{x}=\frac{\sum_{i=1}^{n} x i}{n}
$$


Jika data hasil pengujian kimia berpengaruh nyata, maka akan dilanjutkan dengan uji Beda Nyata Terkecil (BNT). Adapun rumus matematik yang digunakan adalah sebagai berikut (Steel dan Torrie, 1991).

$\mathrm{BNT}=\operatorname{t\alpha } ; \operatorname{dbg} \mathrm{x} \sqrt{\frac{2 .(K T G)}{r}}$

Ket :

$$
\begin{aligned}
& \mathrm{t} \alpha=\text { nilai t pada alfa } 0,05 \text { atau } 0,01 \% \\
& \mathrm{dbg}=\text { derajat bebas galat } \\
& \mathrm{KTG}=\text { kuadrat tengah galat } \\
& \mathrm{r} \quad=\text { ulangan }
\end{aligned}
$$

\section{HASIL DAN PEMBAHASAN}

\subsection{Karakteristik Kimia Biskuit Tepung Tulang Ikan Cakalang}

Karakteristik kimia yang dianalisis pada penelitian ini adalah kadar air, kadar abu, kadar protein, kadar lemak, karbohidrat dan kalsium serta fosfor.

\begin{tabular}{lccc}
\multicolumn{3}{c}{ Tabel .karakteristik kimia biskuit tepung tulan g ikan cakalang } \\
\cline { 2 - 4 } \multicolumn{1}{c}{ Parameter } & $0 \%$ & $4.5 \%$ & $10 \%$ \\
\hline Kadar Air (\%) & $2.01 \pm 0.13$ & $0.98 \pm 0.01$ & $2.38 \pm 0.01$ \\
Kadar Abu (\%) & $1.01 \pm 0.04$ & $1.62 \pm 0.06$ & $2.83 \pm 0.02$ \\
Kadar rotein (\%) & $7.36 \pm 0.44$ & $7.36 \pm 0.45$ & $7.38 \pm 0.44$ \\
Kadar emak (\%) & $22.0 \pm 0.15$ & $20.8 \pm 0.01$ & $22.94 \pm 0.01$ \\
Karbohidrat by difference (\%) & $0.41 \pm 0.41$ & $0.48 \pm 0.19$ & $0.22 \pm 0.11$ \\
kadar Kalsium (\%) & $0.05 \pm 0.01$ & $0.19 \pm 0.01$ & $0.29 \pm 0.01$ \\
Kadar Fosfor (ppm) & $0.03 \pm 0.14$ & $0.13 \pm 0.01$ & $0.20 \pm 0.01$ \\
\hline
\end{tabular}

\subsubsection{Kadar Air}

Disamping sumber air yang nyata berupa air dan minuman lain, hampir semua makanan mengandung air. Sebagian besar buah dan sayuran mengandung sampai 95\% air, sedangkan pada daging umumnya mengandung 50-60\% (Almitser, 2004).

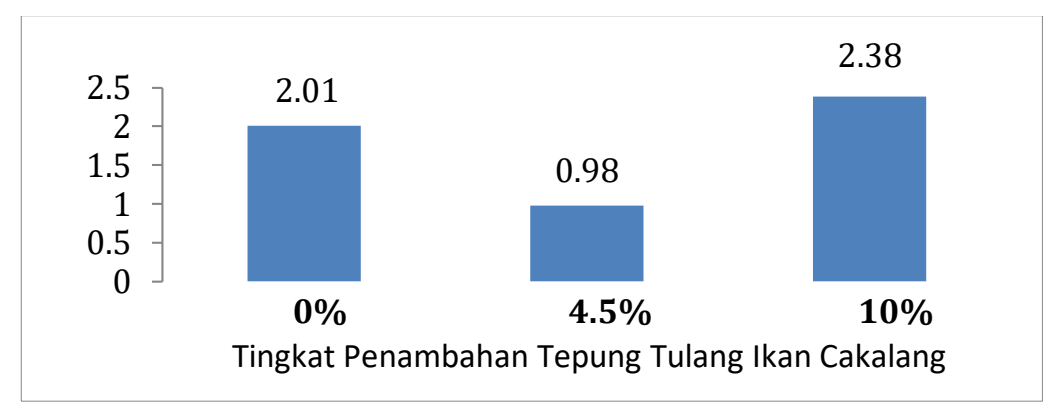

Gambar 3. Rata-rata Kadar Air (ppm)

Berdasarkan grafikpada Gambar 3, kadar air pada biskuit tepung tulang ikan cakalang tertinggi adalah 2,38\% yaitu diperoleh pada perlaakuan $\mathrm{C}$ atau 10\%. Sedangkan nilai terendah adalah 0,8\% yaitu diperoleh pada perlakuan B atau 4.5\%. Grafik di atas juga menunjukan bahwa semakin tinggi penambahan tepung tulang ikan cakalang maka kadar air biskuit tepung tulang ikan cakalang mengalami kenaikan.

Hasil analisis ragam menunjukan bahwa penambahan tepung tulang ikan cakalang memberikan pengaruh nyata terhadap kadar air biskuit tepung tulang ikan cakalang. Selanjutnya hasil uji BNT, disimpulkan bahwa ketiga perlakuan berbeda nyata satu dengan yang lain.

Kenaikan kadar air terjadi pada perlakuan $\mathrm{C}$ atau 10\%, di duga karena dilakukan pengeringan yang kurang lama dibandingkan dengan pengeringan pada perlakuan 0\% (Kontrol) dan 4.5\%. 
Menurut Junianto (2003), suhu pengeringan merupakan faktor yang mempengaruhi nilai kadar air bahan hasil pengeringan.

Semakin tingginya kadar air pada biskuit tepung tulang ikan cakalang menunjukan bahwa penambahan tepung tulang ikan cakalang mengurangi daya awet biskuit. Air dapat digunakan oleh mikroba pembusuk yang dapat menyebabkan pembusukan makanan (Gardjito, 2009). Menurut standar yang ditetapkan oleh Badan Standar Nasional Indonesia, SNI 01-2973-1992 di syaratkan bahwa kadar air pada biskuit maksimum 5\%, sehingga kesemua produk yang dianalisis memenuhi standar SNI.

\subsubsection{Kadar $\mathrm{Abu}$}

Kadar abu dikenal sebagai unsur mineral atau zat organik.Abu merupakan salah satu komponen dalam bahan makanan, komponen ini terdiri dari mineral-mineral seperti kalsium, fosfor, natrium, tembaga (winarno, 1995).

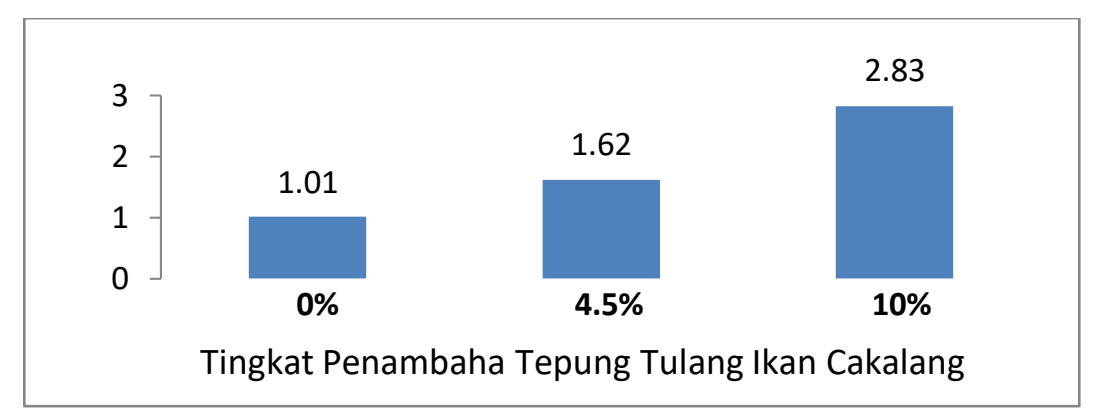

Gambar 4. Rata-rata Kadar Abu

Berdasarkan grafikGambar 4, dapat dilihat bahwa kadar abu bada biskuit tulang ikan cakalang tertinggi adalah $2,83 \%$ yaitu diperoleh pada perlakua $\mathrm{C}$ atau $10 \%$. Sedangkan nilai terendah adalah $1,01 \%$ yaitu diperoleh pada perlakuan Kontrol atau 0\%. Grafik diatas juga menunjukan bahwa semakin tinggi penambahan tepung tulang ikan cakalang maka kadar abu biskuit mengalami kenaikan.

Hasil analisis ragam menunjukan bahwa penambahan tepung tulang ikan cakalang memberikan pengaruk nyata terhadap kadar abu biskuit tepung tulang ikan cakalang. Selanjutnya hasil uji BNT disimpulkan bahwa ketiga perlakuan berbeda nyata satu dengan yang lain.

Sesuai dengan standar yang ditetapkan oleh Badan Standar Nasional ndonesia, SNI 01-29731992 tentang kandungan abu pada biskuit yaitu maksimum sebesar 1,5\%. Dengan demikian produk formulasi biskuit tepung tulang ikan cakalang yang memenuhi standar adalah pada perlakuan $0 \%$ atau (Kontrol).

\subsubsection{Kadar Protein}

Kadar protein merupakan rantai asam amino yang diperlukan oleh tubuh.Protein memiliki peranan penting dalam pertumbuhan (Gardjito, 2009).

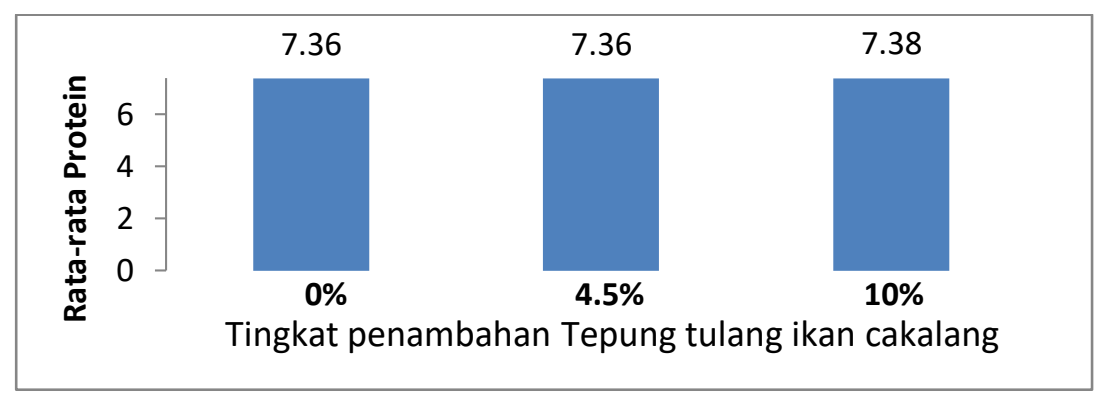

Gambar 5. Rata-rata Kadar Protein

Gambar 5menunjukan bahwa kadar protein pada biskuit tepung tulang ikan cakalang tertinggi adalah 7,83\% yaitu diperoleh pada perlakuan $\mathrm{C}$ atau 10\%. Sedangkan nilai terendah 7,36\% yaitu diperoleh pada perlakuan A dan B atau $0 \%$ dan 4,5\%. Hasil analisis ragam menunjukan bahwa penambahan tepung tulang ikan cakalang tidak memberikan pengaruh nyata terhadap kadar protein biskuit tepung tulang ikan cakalang. 
Peningkatan kadar protein disebabkan oleh semakin banyaknya penambahan tepung tulang ikan cakalang. Menurut Almitser (2004), tulang ikan merupakan salah satu sumber protein yang baik. Mengacu pada kadar protein biskuit berdasarkan SNI 01-2973-1992 yang mensyaratkan kandungan minimum 9\%, maka kesemua produk tersebut tidak memenuhi standar yang ditetapkan.

\subsubsection{Kadar Lemak}

Kadar lemak merupakan sumber energi yang lebih efektif dibandingkan dengan karbohidrat.Satu gram lemak atau minyak dapat menghasilkan 9 kkal energi.Lemak juga berperan sebagai sumber kalsium dan energi (Gardjito, 2009).

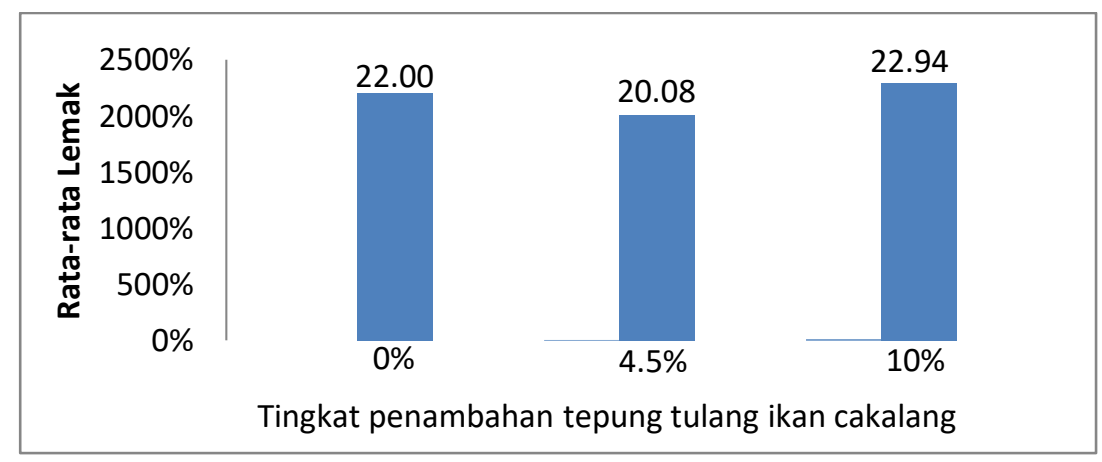

Gambar 6. Rata-rata Kadar Lemak

Gambar 6 menunjukan bahwa kadar lemak pada biskuit tepung tulang ikan cakalang tertinggi adalah $22,94 \%$ yaitu diperoleh pada perlakuan $\mathrm{C}$ atau 10\%. Sedangkan nilai terendah adalah 20,8\% yaitu diperoleh pada perlakuan $\mathrm{B}$ atau $4,5 \%$. Hasil analisis ragam menunjukan bahwa penambahan tepung tulang ikan cakalang memberikan pengaruh nyata terhadap kadar air biskuit tepung tulang ikan cakalang. Selanjutnya hasil uji BNT, di simpulkan bahwa ketiga perlakuan berbeda nyata antara satu dengan yang lain.

Berdasarkan SNI 01-2973-1992 mensyaratkan kandungan minimum lemak adalah 9,5\%, sehingga kesemua produk memenuhi persyratan tersebut. Kandungan lemak yang tinggi pada produk biskuit tepung tulang ikan cakalaang berasal dari bahan-bahan yang digunakan dalam formulasi terutaama mentega dan tepung tulang ikan.

\subsubsection{Karbohidrat by difference}

Kadar kabrbohidrat ditentukan dengan by difference yaitu hasil pengurangan dari $100 \%$ dengan kadar air, kadar abu, kadar protein dan kadar lemak sehingga kadar karbohidrat tergantung pada factor pengurangannya. Hal ini disebabkan karena karbohidrat sangat berpengaruh pada factor kandungan zat gizi lainnya. Penentuan dengan cara ini kurang akurat dan merupakan perhitungan kasar sebab karbohidrat yang dihitung termasuk serat kaasar yang tidak menghasilkan energi (Winarno, 1997). Rata-rata analisis kadar karbohidrat pada biskuit tepung tulang ikan cakalang dapat dilihat pada grafik berikut.

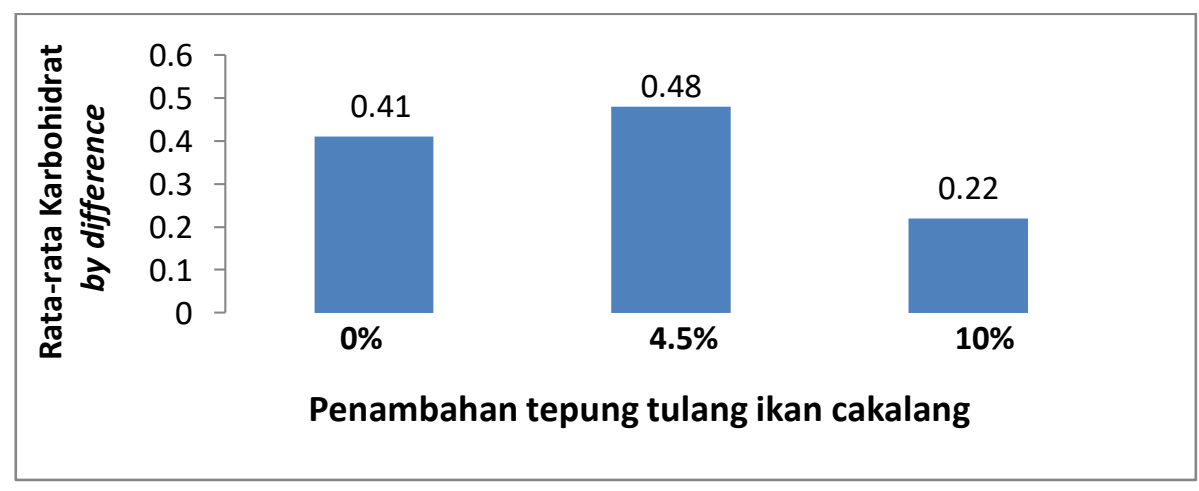

\section{Gambar 7. Rata-rata Kadar Karbohidrat}

Gambar 7.menunjukan bahwa kadar karbohidrat pada biskuit tepung tulang ikan cakalang tertinggi adalah $0,48 \%$ yaitu diperoleh pada perlakuan B atau 4,5\%. Sedangkan nilai terendah adalah $0,22 \%$ yaitu diperoleh pada perlakuan C atau $10 \%$. Hasil analisis raagam menunjukan bahwa penambahan 
tepung tulang ikan cakalang tidak memberikan pengaruh nyata terhadap kadar karbohidrat biskuit tepung tulang ikan.

Menurut SNI 01-2973-1992 kadar karbohidrat minimum adalah 70\%. Dengan demikian maka produk formulasi biskuit tepung tulang ikan cakalang yang dibuat belum memenuhi standar yang telah ditetapkan, karena kandungan karbohidrat pada masing-masing formulasi hanya 0,41\%, 0,48\% dan $0,22 \%$.

\subsubsection{Kadar Kalsium}

Unsur organik yang paling penting di dalam tubuh dan dalam jumlah terbanyak adalah kalsium. Unsur ini terdapat pada pakan hewan dan makanan manusia seperti pada tulang, susu dan sayuran. Sekitar 99\% kalsium di dalam tubuh terdapat di dalam tulang dan gigi (Thalib, 2008). Ratarata hasil analisis kadar kalsium pada biskuit tepung tulang ikan cakalang dapat dilihat pada grafik berikut.

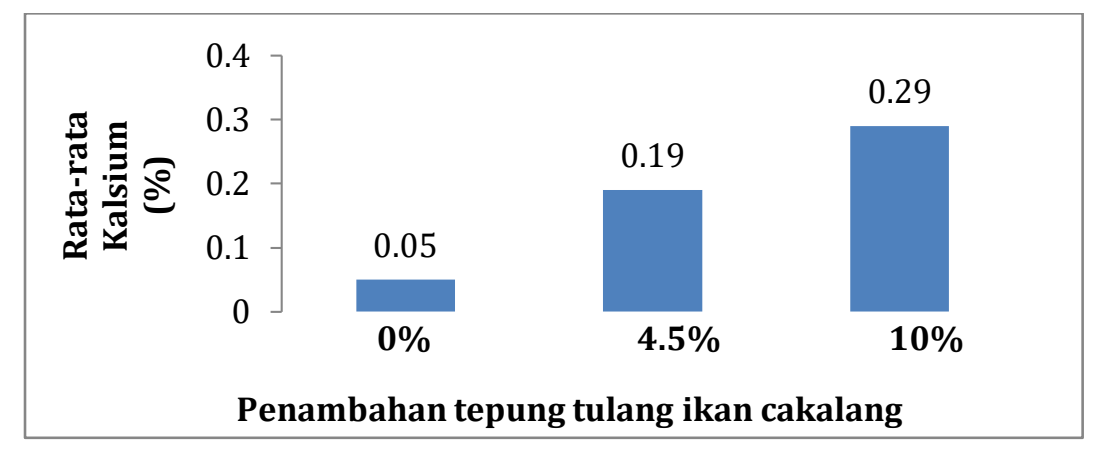

\section{Gambar 8. Rata-rata Kadar Kalsium}

Gambar 8 dapat dilihat bahwa kadar kalsium pada biskuit tepung tulang ikan cakalang tertinggi adalah $0,29 \%$ yaitu diperoleh pada perlakuan $\mathrm{C}$ atau $10 \%$. Sedangkan nilai terendah adalah 0,05\% yaitu diperoleh pada perlakuan A (Kontrol) atau 0\%. Graif diatas juga menunjukan bahwa semakin tinggi penambahan tepung tulang ikan cakalang maka kadar kalsium biskuit tepung tulang ikan juga mengalami peningkatan. Hasil analisis ragam menunjukan bahwa penambahan tepung tulang ikan cakalang tidak memberikan pengaruh nyata terhadap kadar kalsium biskuit tepung tulang ikan cakalang.

Tingginya kandungan kalsium pada biskuit disebabkan karena semakin banyak penambahan tepung tulang ikan cakalang maka semakin tinggi pula kandungan kalsium. Tepung tulang ikan cakalang mempunyai kandungan kalsium yang tinggi disamping itu komponen tambahan kalsium lain yang bersumber dari telur dan mentega (Almatsier, 2003).

\subsubsection{Kadar Fosfor}

Fosfor merupakan komponen mineral kedua terbanyak dalam tubuh manusia dan cukup penting peranannya karena bersama dengan kalsium akan membentuk struktur tulang dan gigi (Almatsier, 2003). Rata-rata hasil analisis kadar fosfor pada biskuit tepung tulang ikan cakalang dapat dilihat pada grafik berikut.

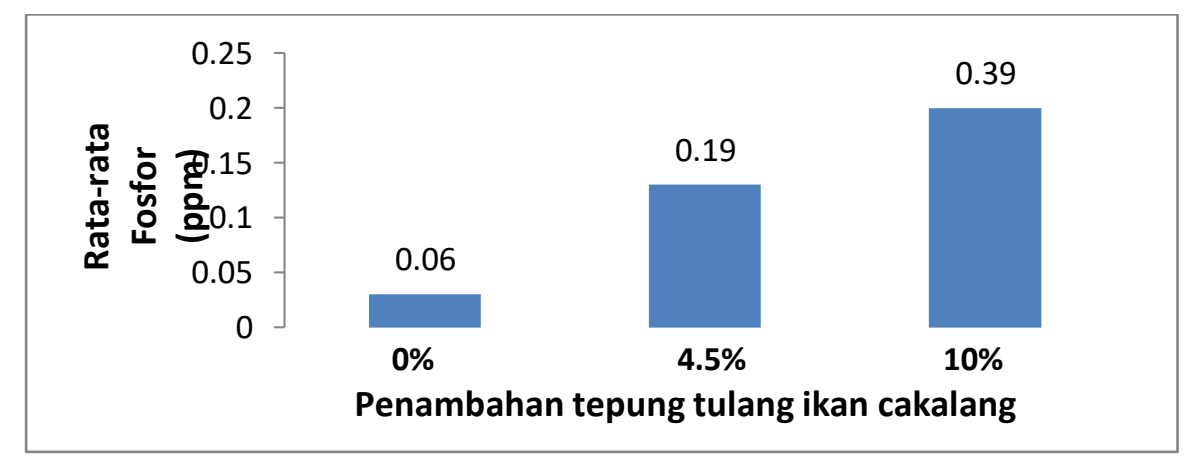

\section{Gambar 9. Rata-Rata Kadar Fosfor}

Grafik 9 menunjukan bahwa kadar fosfor pada biskuit tepung tulang ikan cakalang tertinggi adalah $0,39 \mathrm{ppm}$ yaitu diperoleh pada perlakuan $\mathrm{C}$ atau $10 \%$. Sedangkan nilai terendah adalah 0,06 
ppm yaitu diperoleh pada perlakuan A(Kontrol) atau 0\%. Grafik diatas juga menunjukan bahwa semakin tinggi penambahan tepung tulang ikan cakalanng maka kadar fosfor semakin meningkat. Hasil analisis ragam menunjukan bahwa penambhan tepung tulang ikan cakalang memberikan pengaruh tidak nyata terhadap kadar fosfor biskuit tepung tulang ikan cakalang.

Tingginya kandungan fosfor seiring dengan tingkat penambahan tepung tulang ikan cakalang ini diduga karena kandungan fosfor yang terdapat dalam tulang ikan cakalang cukup tinggi ditambah dengan sumber lain yaitu mentega dan telur (Thalib, 2008).

\section{PENUTUP}

\subsection{Kesimpulan}

Dari hasil penilitian dapat disimpulakan bahwa darai hasil uju kimia menunjukan bahwa hasil kadar air (2,01\%, 2,38\%), kadar abu (1,01\%, 2,83\%), dan kadar lemak (22,00\%, 22,94\%) memberikan pengaruh nyata terhadap biscuit tepung tulang ikan cakalang, sedangkan protein, karbohidrat by difference, kalsium dan fosfor memberikan pengaruh tudak nyata terhadap biscuit tepung tulang ikan cakalang.

\subsection{Saran}

1. Perlu adanya penilitian lanjutan dengan bahan baku tepung tulang ikan yang berbeda, sebagai sumber kalsium dan fosfor.

2. Pemanfatan tepung tulalang ikan cakalang sebagai sumber kalsium dan fosfor pada produk lain.

\section{DAFTAR PUSTAKA}

Almatsier S. 2003. Prinsip Dasar Ilmu Gizi. Jakarta: Gramedia Pustaka.

Anggreani D. 2003, Analisis Mineral Plasma Darah.[Standard Operating Prosedure].Bogor Fakultas Peternakan, Institut Pertanian Bogor.

Anonim. 2008. http//ww. Indoskripsi.Tepung tulang ikan.[Diakses 20 Maret 2010].

Artama T. 2001. Pemanfaatan tepung ikan lemuru (Sardinela longceps) untuk meningkatkan mutu fisik dan nilai biskuit [tesis]. Bogor: Program Pascasarjana, Institut Pertanian Bogor.

Dahuri R. 2004. Gerakan Makan Ikan, Budaya Bahari dan Kualitas Hidup Bangsa, Harian Kompas, Jakarta.

Gardjito M. 2009. Pengolahan Pangan dan Gizi, Pusat Kajian Makanan Tradisional. Universitas Gajah Mada (UGM) Yogyakarta.

Gazperz V. 1991. Metode Rancangan Percobaan. CV. Amirco. Bandung.

Junianto. 2003. Produksi gelatin dari tulang ikan dan pemanfaatannya sebagai bahan dasar pembuatan cangkang kapsul. Fakultas Perikanan Dan Ilmu Kelautan Universitas Pedjajaran

Manley D. 2001.Biscuit, crackers and cookies recepies for food industry. Westport Conecticut: AVI Publishing Company Inc.

Raitz LL, Smith WH, PlumleeMP. 1987. A Simple Wet Oxidation Prosedure for Biological Materials. Wets Lafayete: Animal Science Purdue University.

[SNI] Standarisasi Nasional Indonesia. SNI 01-2973-1992.Mutu dan Cara Uji Biskuit. Jakarta: Bharatara Karya Aksara.

Steel RGD dan Torrie JH. 1991. Prinsip dan Prosedur Statestika. Penerjemah: Sumantri B. Jakarta: PT. Gramedia Pustaka Utama.

Tangke, U., Karuwal, J. W. C., Mallawa, A., \& Zainuddin, M. 2017. Analisis Hubungan Suhu Permukaan Laut, Salinitas, Dan Arus Dengan Hasil Tangkapan Ikan Tuna Di Perairan Bagian Barat Pulau Halmahera. Jurnal IPTEKS Pemanfaatan Sumberdaya Perikanan, 3(5).

Tangke, U., Mallawa, A., \& Zainuddin, M. 2011. Analisis hubungan karakteristik oseanografi dan hasil tangkapan yellowfin tuna (Thunnus albacares) di perairan Laut Banda. Agrikan: Jurnal Agribisnis Perikanan, 4(2), 1-14. DOI: 29239/j.agrikan.4.2.1-4 
Tangke U., 2014. Parameter populasi dan tingkat eksploitasi ikan tongkol (Euthynnus affinis) di perairan Pulau Morotai. Agrikan: Jurnal Ilmiah Agribisnis dan Perikanan. 7(1):74-81. DOI: 10.29239/j.agrikan.7.1.74-81.

Tangke U., Deni S., \& Aunaka A., 2018a. The Influence of Using Bait Types to the Number and Composition of Fishing Traps Catch in South Ternate Waters. IOP Conference Series: Earth and Environmental Science. 175(1):12231. DOI: 10.1088/1755-1315/175/1/012231.

Tangke U., Mallawa A., \& Zainuddin M., 2011. Analisis hubungan karakteristik oseanografi dan hasil tangkapan yellowfin tuna (Thunnus albacares) di perairan Laut Banda. Agrikan: Jurnal Agribisnis dan Perikanan. 4(2):1-14. DOI: 10.29239/j.agrikan.4.2.1-14.

Tangke U., Sangadji I., Rochmady R., \& Susiana S., 2018b. A population dynamic aspect of Selaroides leptolepis in the coastal waters of South Ternate Island, Indonesia. AACL Bioflux. 11(4):13341342.

Thalib A. 2008. Pemanfaatan tepung tulang ikan madidihang sebagai sumber kalsium dan fosformeningkatkan nilai gizi makron kenari [tesis].Bogor:Jurusan Teknologi Hasil Prikanan,Institut Pertanian Bogor.

Winarno FG. 1985. Limbah Perikanan. Kantor Menteri Muda Urusan Peningkatan Produksi Pangan. Jakarta.

Winarno FG. 1997. Kimia Pangan dan Gizi.Jakarta: Gramedia Pustaka. 